УДК 327.7-027.541(478:4/.5)(091)

Нарміна Мамішова,

аспірантка спеціальності «Міжнародні відносини, суспільні

комунікації та регіональні студії»,

Інститут міжнародних відносин,

Київський національний університет імені Т. Г. Шевченка,

narminamamishova@gmail.com

DOI 10.29038/2524-2679-2020-02-293

\title{
УЧАСТЬ РЕСПУБЛІКИ МОЛДОВА В ОРГАНІЗАЦІї ЗА ДЕМОКРАТІЮ ТА ЕКОНОМІЧНИЙ РОЗВИТОК (ОДЕР-ГУАМ): ВІД ПРЕЗИДЕНТСТВА П. ЛУЧИНСЬКИ ДО ПРЕЗИДЕНТСТВА М. САНДУ
}

Організаиія за демократію та економічний розвиток ОДЕР-ГУАМ була створена понад два десятиліття тому як платформа дружньої співпраці між кількома пострадянськими краӥнами, прихильними до євроатлантизму. У 2006 р. групування перетворено на повноцінну міжнародну організацію, яка об'єднала Грузію, Украӥну, Азербайджан та Молдову. На жаль, вважається, що організачії так $і$ не вдалося перетворитися на потужну платформу політичної координації та багатовекторного співробітництва для держав-членів. Одним із факторів вилучення організаиії з "великої гри» залишається амбівалентність внутрішньополітичних настроїв у країнахучаснииях, що ставить в залежність характер членства в ОДЕР-ГУАМ від лідерів, які перебуваються при владі в тій чи іншій країні. Значною мірою така тендениія стосується Республіки Молдова, яка, з огляду на нестабільну внутрішньополітичну кон'юнктуру, досі не реалізувала свій національний інтерес щодо членства в ОДЕР-ГУАМ, залишаючись осторонь інтеграційного процесу в організаиії та поза ї̈ амбітними міжнародними проєктами, у тому числі в галузі енергетики та транспорту із залученням територій країн «четвірки».

Незважаючи на геостратегічну роль, яку відграє співробітництво в рамках ОДЕР-ГУАМ у питаннях європейських та євроатлантичних прагнень новоутворених пострадянських республік, стримування політикоекономічної експансї євразійських інтеграційних проєктів, спільності загроз актуальних та заморожених збройних конфліктів у регіоні ОДЕРГУАМ, перспективності торговельно-економічних проєктів, а також актуальності забезпечення європейської енергетичної безпеки, організа- 
ція до сьогодні не знаходила належної уваги з боку науковиів. Водночас ичи, бракує теоретичного та прикладного вивчення патернів членства окремих країн-членів організації, у тому числі Молдови. У статті здійснено аналіз внутрішньополітичних аспектів участі Республіки Молдова в інтеграційному проєкті ОДЕР-ГУАМ. Зокрема, розглянуто ключові тендениії членства країни в ОДЕР-ГУАМ за хронологією часів президентства П. Лучинськи, В. Вороніна, Н. Тімофті, І. Додона. Водночас оиінено перспективи подальшої долі Молдови як члена міжнародної регіональної організачії після перемоги на президентських виборах 2020 р. М. Санду.

Ключові слова: ОДЕР-ГУАМ, Молдова, Кишинів, міжнародна регіональна організачія, Лучинськи, Воронін, Тімофті, Додон, Санду.

\section{1. ВСТУП}

ОДЕР-ГУАМ є молодою міжнародною регіональною організацією, статутні члени якої - Грузія, Україна, Азербайджанська Республіка та Республіка Молдова. Із 1999 по 2005 р. до альянсу також входила Республіка Узбекистан. Ідеологічно поява в 1997 р. на той час міждержавного угруповання стала, з одного боку, відповіддю на амбіції сусідньої Росії щодо реінтеграції колишніх радянських республік навколо СНД під егідою Москви, з іншого чотири країни вбачали перспективу об'єднання зусиль щодо реалізації - не обов'язково категоричної - зовнішньополітичних прагнень до європейської та євроатлантичної інтеграції. Водночас заснування ОДЕР-ГУАМ як політичного, економічного та стратегічного альянсу було відображенням об'єктивної тенденції до розвитку самоорганізованого регіонального плюралізму, у якому держави, об'єднані спільними зовнішньополітичними пріоритетами та цінностями, національними інтересами й викликами, прагнули посилення «добровільних» форматів співпраці. У 2006 р. ОДЕРГУАМ перетворено на повноцінну міжнародну організацію, яка залишається важливою складовою частиною загальноєвропейської і євроазіатської політико-безпеково-економічної архітектури.

\section{2. РЕЗУЛЬТАТИ ДОСЛІДЖЕННЯ}

Згідно зі Стратегією національної безпеки України, затвердженою Указом Президента від 14 вересня 2020 р. [1], офіційний Київ розглядає Азербайджан та Грузію своїми стратегічними партнерами, у той час як у випадку з Молдовою (поряд із Білоруссю) посилається на розвиток прагматичних відносин. 
Незважаючи на те, що документ стосується національних інтересів та пріоритетів забезпечення національної безпеки лише однієї з держав-членів ОДЕР-ГУАМ, така «класифікація» чітко визначає тенденції інтеграційного процесу в рамках організації. На жаль, вважається, що серед чотирьох республік саме Молдова завжди була найменш зацікавленою й, відповідно, найменш залученою до цього процесу країною-членом. Саме Молдові, за іронією долі, в абревіатурі «ГУАМ» відведений останній номер, що цілком відповідає характеру самосприйняття держави як частини угруповання 3 моменту його утворення та до сьогодні. Переважно саме офіційний Кишинів висловлював недовіру до перспективності організації, виступав проти посилення ii iнституалізації й займав скоріше позицію спостерігача, аніж повноправного й залученого учасника альянсу.

Молдова-ГУАМ: від П. Лучинськи. Із боку Кишинева підписання Страсбурзької декларації 10 жовтня 1997 р. в рамках саміту Ради Свропи [2], яке ознаменувало утворення ОДЕР-ГУАМ як Дорадчого форуму, припало на часи президентства Петру Лучинськи. Колишній член Політбюро ЦК КПРС, за кілька років після розпаду Радянського Союзу він став другим Президентом Молдови й обіймав цей пост із 1996 по 2001 р. Саме Лучинськи на національному рівні продовжив рух у напрямі «молдовізації» та підтримував виведення генеалогії пострадянської Молдови від держави Стефана Великого [3]. Ініціатива ж щодо приєднання до ОДЕР-ГУАМ своєрідна «червона ганчірка» для Росії - характеризувала його політику як стратегічно схильну в бік Свропи. У той самий час Петру Лучинськи наполягав на нейтральному статусі Молдови, закріпленому в Конституції 1994 р. [4], котрий унеможливлює воєнно-політичні відносини як із НАТО, так і з ОДКБ. Відповідно, Кишинів від самого початку виступав проти розвитку військової складової частини співробітництва в рамках ОДЕР-ГУАМ [5], маючи намір обмежитись інтеграцією винятково навколо економічних проєктів.

Володимир Воронін, який прийшов до влади у 2001 р., залишився досить суперечливою фігурою в історії трансформації угруповання. Саме він виступив на Ялтинському саміті 2002 р. із заявою про те, що очікує «політичних дивідендів» від членства своєї країни в ОДЕР-ГУАМ [6]. Здебільшого мається на увазі неврегульований конфлікт у Придністров’”̈, який був одним із ключових рушіїв для Молдови приєднатися до ОДЕРГУАМ у пошуках політичної підтримки. Водночас у рамках саміту озвучено занепокоєння Кишинева щодо фактичного виключення країни з транспортноенергетичних проєктів «четвірки» [7]. Із виходом же Узбекистану 3 угруповання (і подання «поганого прикладу») республіка стала «слабкою 
ланкою» в ОДЕР-ГУАМ [8], а Президент Молдови заявляв про можливість такого кроку також і з боку Кишинева. У будь-якому разі саме Володимир Воронін «схвалив» членство Молдови в ОДЕР-ГУАМ як у повноцінній міжнародній регіональній організації на Київському саміті 2006 р.

Саміти ОДЕР-ГУАМ у Баку 2007 р. та в Батумі 2008 р. виявили подальше відсторонення Молдови від діяльності організації. Президент Воронін не взяв участь в обох, натомість Молдову представляли прем'єрміністр та міністр внутрішніх справ відповідно. Такий тренд спричинений значною мірою сподіваннями офіційного Кишинева на підтримку Кремля у вирішенні придністровського конфлікту [9]. Загальна картина була ще більш песимістичною: у своїй риториці Президент Молдови неодноразово посилався на марність організації, що лише посилювало занепокоєння 3 приводу можливого виходу Молдови з ОДЕР-ГУАМ. У більш широкому контексті цьому сприяла низка зовнішніх чинників: погіршення відносин між Москвою й Києвом унаслідок газової війни, переконаність у недостатній увазі до інтересів Молдови з боку Баку та Тбілісі, а також відсутність реальних перспектив щодо європейської інтеграції для держав-членів організації [10]. Подальша політична турбулентність навколо парламентських і президентських виборів у Молдові у 2009 р. й обрання прихильного до Росії Президента Віктора Януковича в Україні у 2010 р. викликали сумніви щодо майбутнього Молдови в ОДЕР-ГУАМ [11]. Після скандальної відставки Володимира Вороніна Кишинів увійшов у майже трирічну фазу відсутності стабільної влади з вересня 2009 р., тож країні було не до ОДЕР-ГУАМ.

Саме за президентства Вороніна було вперше зруйновано загальноприйнятий стереотип, сформований за роки існування ОДЕР-ГУАМ, який позиціонував «вольове» об'єднання чотирьох країн-однодумців - Грузії, України, Азербайджану та Молдови - як символ міждержавної солідарності на пострадянському просторі. Значною мірою таке уявлення знаходило свої відображення у взаємній політичній та дипломатичній підтримці на міжнародній арені насамперед у рамках Генеральної Асамблеї ООН, Парламентської асамблеї Ради Свропи та Парламентської асамблеї ОБСС. Для Азербайджану це стосується голосування «за» резолюцію 62/243 Генеральної Асамблеї ООН «Ситуація на окупованих територіях Азербайджану» від 14 березня 2008 року як знак підтримки з боку Грузії, України та Молдови (поряд із всього 36 іншими державами) [12]. Для офіційного Києва - прояву Азербайджаном, Грузією та Молдовою солідарності у ставленні до воєнно-політичної ситуації в Україні своїми голосами «за» резолюцію 68/262 стосовно територіальної цілісності України 27 березня 2014 р. [13]. За аналогією, достатньо показовою в частині узгодженості між чотирма республіками стала сімдесят друга сесія Генеральної 
Асамблеї ООН: ідеться про резолюцію 72/280 про право на повернення всіх внутрішньо переміщених осіб та біженців до їхніх домівок по всій території Грузії, у тому числі в Абхазії та Цхінвальському регіоні/Південній Осетії, від 12 червня 2018 р. [14], а також резолюцію 72/282 під назвою «Повне та безумовне виведення іноземних військових сил з території Республіки Молдова» від 22 червня 2018 p. [15].

Молдова під керівництвом Володимира Вороніна започаткувала практику відхилення від єдиних позицій країн-членів ОДЕР-ГУАМ на міжнароднополітичних майданчиках. Так, Азербайджан та Україна увійшли до числа 14 «сміливців», які продемонстрували солідарність із Грузією щодо резолюції 62/249 від 15 травня 2008 року про визнання права всіх біженців та внутрішньо переміщених осіб на повернення до Абхазії [16], у той час як Молдова утрималася від голосування. Рішення офіційного Кишинева стало безпрецедентним на той час, адже резолюція була представлена фактично як «колективна», тобто яка звертається до проблем безпеки не лише Грузії безпосередньо, але й двох інших держав-членів ОДЕР-ГУАМ. Так, закликаючи спільноту ООН підтримати резолюцію, представник України Юрій Сергєєв заявив, що «конфлікти в регіоні залишаються головною перешкодою для демократичного та економічного розвитку Азербайджану, Молдови та Грузії. Вони повинні бути врегульовані шляхом безумовного визнання принципів територіальної цілісності та прав людини». Постійний представник Азербайджану при ООН Агшин Мехдієв заявив, що «випадки вимушеного переміщення осіб в регіоні ОДЕР-ГУАМ загрожують не лише стабільності в регіоні, а й усьому світу, і є наслідком агресивного сепаратизму з метою використання сили для кардинальної зміни демографічного складу постраждалих територій».

Прозахідний президент Ніколае Тімофті, який прийшов до влади в березні 2012 р. у результаті парламентського голосування, визначив європейську зовнішньополітичну орієнтацію Молдови пріоритетною, що за замовчуванням викликало надію на повернення Кишинева до «сім'і ОДЕР-ГУАМ». Однак на тлі нестабільного політичного клімату в країні та зовнішнього тиску він здебільшого не надавав серйозного значення участі країни в організації [12]. У таких умовах Президент Тімофті передав владу своєму наступнику, одному із лідерів Партії соціалістів Республіки Молдова Ігорю Додону. Проросійська позиція останнього та, відповідно, чутливість до антагонізму Кремля стосовно до ОДЕР-ГУАМ окреслили невпевнену позицію Молдови щодо організації. Так, наприклад, у квітні 2017 p. Президент Додон ініціював процедуру отримання Молдовою статусу спостерігача в Свразійському економічному союзі [13]. Часи його президентства характеризувалися суперництвом між політичними таборами в 
парламенті, що симпатизують СС і Росії.

Молдова-ГУАМ: до М. Санду. Перемога на президентських виборах у Молдові в листопаді 2020 р. прозахідного політика Маї Санду може дати новий поштовх, передусім, відносинам Кишинева з Україною. Так, українсько-молдовські взяємини мають шанс на повернення на стратегічний рівень з огляду на географічне сусідство, спільність проблем європейської безпеки, а також відтепер - одностайність позицій лідерів двох держав стосовно європейської та євроатлантичної інтеграції. Зі свого боку, згідно з Конституцією, Молдова $\epsilon$ парламентсько-президентською республікою, у парламенті якої соціалісти й проєвропейські політичні сили представлені майже однаково та через діаметрально протилежні ідеологічні погляди навряд зможуть сформувати коаліцію [14]. Цей фактор пояснює за аналогією неспроможність прихильного до Кремля Ігоря Додона протягом свого президентства здійснити стратегічний поворот зовнішньополітичного курсу країни в бік інтеграційних проєктів під егідою Росії.

Що стосується потенційного впливу результатів президентських виборів у Молдові на інтеграційний процес у рамках ОДЕР-ГУАМ у цілому, то, на жаль, значного посилення координації між державамичленами не очікується. 3 одного боку, для Азербайджану пріоритетним є контрольований та справедливий вихід із нагірно-карабаського конфлікту. Так, незважаючи на те, що військова операція азербайджанської армії на окупованих Вірменією територіях завершилася 10 листопада фактичною перемогою для наступаючої сторони [15], зарано ще говорити про остаточне оформлення мирного процесу в Нагірному Карабасі. 3 іншого боку, для Грузії нагальним є розв'язання внутрішньополітичних проблем на тлі парламентських виборів 31 жовтня, які призвели до невизнання результатів iз боку опозиції й загострили тривалу політичну кризу в країні [16]. Зі свого боку, саме Грузія в порядку ротації має прийняти від Азербайджану головування в ОДЕР-ГУАМ у 2021 р., у рамках якого очікується більшою мірою зосередження уваги на питаннях безпеки в контексті загроз територіальній цілісності й суверенітету чотирьох республік у межах їхніх міжнародно визнаних кордонів.

\section{3. ВИСНОВКИ ТА ПЕРСПЕКТИВИ ПОДАЛЬШИХ ДОСЛІДЖЕНЬ}

У будь-якому разі абсолютно зумовленою $є$ необхідність актуалізації порядку денного співробітництва в рамках ОДЕР-ГУАМ. Це стосується, передусім, недостатньої консолідації учасників інтеграційного проєкту навколо ключових зовнішньополітичних питань, зокрема актуальних i заморожених збройних конфліктів на територіях усіх чотирьох держав. Потенційно Молдова (традиційно найменш активний учасник ОДЕР-ГУАМ) «формату» президентства 
Маї Санду, а не Ігоря Додона, могла відмовитися від очікуваної політики «мовчання» щодо нещодавньої ескалації нагірно-карабахського конфлікту. За аналогією потенційно Молдова «формату» президентства Маї Санду, а не Володимира Вороніна, замість утримання від голосування, могла приєднатися до числа 14 «сміливців», які продемонстрували солідарність із Грузією стосовно резолюції від 15 травня 2008 р. про визнання права всіх біженців та внутрішньо переміщених осіб на повернення до Абхазії [17]. Отже, результати цьогорічних президентських виборів у Молдові, незважаючи на внутрішньоконституційні обмеження в частині повноважень голови держави, залишають надію на консолідацію зусиль Кишинева щодо перетворення ОДЕР-ГУАМ на символ міждержавної солідарності на пострадянському просторі.

\section{СПИСОК ВИКОРИСТАНИХ ДЖЕРЕЛ}

1. Офіційне інтернет-представництво Президента України. Указ Президента України №392/2020 «Про рішення Ради національної безпеки і оборони України від 14 вересня 2020 року «Про Стратегію національної безпеки України»; Президент (2020). URL: https://www.president.gov.ua/documents/3922020-35037.

2. Organization for Democracy and Economic Development - GUAM (1997). Joint Communique of the Meeting of the President of Azerbaijan, Georgia, Moldova and Ukraine. Retrieved from https://guam-organization.org/en/joint-communique-ofthe-meeting-of-the-president-of-azerbaijan-georgia-moldova-and-ukraine-strasbourgoctober-10-1997.

3. Україна модерна, вип. 14-15/Львівський нац. ун-т ім. Івана Франка; Ін-т іст. дослідж., 2009, 211.

4. Minorities at Risk Project. Chronology for Slavs in Moldova. Refworld (2004). URL: https://www.refworld.org/docid/469f38be17.html.

5. Skakov, A. (2008). Russia and GUAM. Central Asia and the Caucasus (Special Issue), 3-4 (51-52), 142-156.

6. Ivanov, V. (2009). GUAM: Old problems and new challenges. Central Asia and the Caucasus, 4-5 (58-59), 152-159.

7. Pinzar, S. (2008). Moldova-GUAM. Central Asia and the Caucasus (Special Issue), 3-4 (51-52), 126-134.

8. Goble, P. (2009, January 29). Is Moldova about to leave GUAM? Azerbaijan International. Retrieved from https:/www.azer.com/aiweb/categories/caucasus_crisis/ index/cc_articles/goble/goble_2009/goble_0109/goble_0128_moldova.html.

9. Bugajski, J. (2009). Dismantling the West: Russia's Atlantic agenda. Washington, D.C.: Potomac Books, Inc., 257 p., p. 84.

10. Goble, P. (2009, January 29). Is Moldova about to leave GUAM?. Azerbaijan International. Retrieved from https:/www.azer.com/aiweb/categories/caucasus_crisis/ index/cc_articles/goble/goble_2009/goble_0109/goble_0128_moldova.html.

11. Cottey, A. (2012). The other Europe: Regional security governance in Europe's East. In S. Breslin \& S. Croft (Eds.), Comparative regional security governance. Abingdon: Routledge, 222 p., p. 51. 
12. Офіційний веб-сайт Організації Об’єднаних Націй. Резолюція Генеральної Асамблеї ООН 62/243 від 14 березня 2008 року «Ситуація на окупованих територіях Азербайджану» (2008). URL: https://www.un.org/press/en/2008/ga10693.doc.htm.

13. Офіційний веб-сайт Організації Об'єднаних Націй. Резолюція Генеральної Асамблеї ООН 68/262 від 27 березня 2014 року «Територіальна цілісність України» (2014). URL: https://digitallibrary.un.org/record/767883?ln=ru.

14. Civil.ge (2018, June 13). UN General Assembly Passes Georgia IDP Resolution. Civil.ge. Retrieved from https://civil.ge/archives/244195.

15. Moldova.org (2018, June 22). UN General Assembly adopts Moldova's resolution on withdrawal of «foreign military forces» from its territory. Moldova.org. Retrieved from https://www.moldova.org/en/un-general-assembly-examine-moldovas-resolution-withdrawal-foreign-military-forces-territory.

16. Офіційний веб-сайт Організації Об’єднаних Націй. Резолюція Генеральної Асамблеї ООН 62/249 від 15 травня 2008 року «Статус внутрішньо переміщених осіб та біженців з Абхазії, Грузія» (2008). URL: https://www.un.org/press/en/2008/ ga10708.doc.htm.

17. Гуткин М. (2012, 27 сентября). Президент Молдовы призвал вывести российские войска с территории его страны. Голос Америки. Режим доступа к ресурсу: https:/www.golosameriki.com/a/un-moldova-timofti/1515699.html.

18. Офіційний веб-сайт Організації Об’єднаних Націй. Резолюція Генеральної Асамблеї ООН 67/268 від 13 червня 2013 року «Статус внутрішньо переміщених осіб та біженців з Абхазії, Грузія, та регіону Цхінвалі/Південна Осетія, Грузія» (2013). URL: https://undocs.org/en/A/RES/67/268.

19. Foreign Policy Association of the Republic of Moldova. (2012, July 13). Interview with the President of the Republic of Moldova, Nicolae Timofti, to the Lithuanian website eurodialogue.org. Retrieved from http:/www.ape.md/en/2012/07/english-interview-withthe-president-of-the-republic-of-moldova-nicolae-timofti-to-the-lithuanian-website-httpeurodialogue-org.

20. Niu, Q. (2017, June 12). Can China help GUAM diversify away from Russia? Eurasianet. Retrieved from https://eurasianet.org/can-china-help-guam-diversify-away-fromrussia.

21. Офіційне інтернет-представництво Президента України. Загострення в Нагірному Карабасі свідчить, що будь-який заморожений конфлікт може розгорітися знову навіть через багато років. Президент (2020). URL: https:/www.president.gov.ua/ news/zagostrennya-v-nagirnomu-karabasi-svidchit-sho-bud-yakij-zam-64237.

22. Civil.ge (2020, October 5). Georgian President Talks Nagorno-Karabakh, Tbilisi's Neutrality. Civil.ge. Retrieved from https://civil.ge/archives/37

23. Lenta.ru (2020, 30 Ноября). Санду сравнила конфликты в Приднестровье и Нагорном Карабахе. Lenta.ru. Режим доступа к ресурсу: https:/lenta.ru/news/2020/11/30/ pridnebah.

24. Паливода, В. (2019, 1 червня). «Заморожені» конфлікти на пострадянському просторі як виклик європейській безпеці. Національний інститут стратегічних досліджень. URL: https://niss.gov.ua/en/node/170. 
25. Савицкий, В. (2020, 17 Ноября). Россия не пойдёт на обострение ситуации в Приднестровье из-за победы Санду в Молдове. UA.NEWS. URL: https:/ua.news/ $\mathrm{ru} /$ rossyya-ne-pojdyot-na-obostrenye-sytuatsyy-v-prydnestrove-yz-za-pobedy-sandu-vmoldove.

26. Аксьонов, П. (2020, 12 листопада). Чому Азербайджан виграв війну у Карабаху? Відповідають військові експерти. BBC News Україна. URL: https://www. bbc.com/ukrainian/features-54912350.

27. Шелест, А. (2020, 3 ноября). Выборы, что лишь усугубили кризис: будет ли в Грузии новый майдан. Европейская правда. URL: https://www.eurointegration.com.ua/ rus/articles/2020/11/3/7116038

\section{PARTICIPATION OF THE REPUBLIC OF MOLDOVA IN THE ORGANIZATION FOR DEMOCRACY AND ECONOMIC DEVELOPMENT (ODED-GUAM): FROM THE PRESIDENCY OF P. LUCZYNSKI TO THE PRESIDENCY OF M. SANDU}

The ODED-GUAM Organization for Democracy and Economic Development was originated more than two decades ago as a friendly cooperative forum of a few post-Soviet countries committed to Euro-Atlanticism. In 2006, the grouping was transformed into a full-fledged international organization bringing together Georgia, Ukraine, Azerbaijan, and Moldova. Unfortunately, the organization has failed to become a powerful platform for political coordination and multi-vectorial cooperation between its member states. One of the factors that excludes the organization from the 'big game' is the ambivalence of domestic political climate in the participating countries, which makes the nature of membership in ODEDGUAM dependent on leaders in power in each individual country. To a large extent, this trend applies to the Republic of Moldova, which, given the unstable internal political situation, has not yet realized its national interest towards membership in ODED-GUAM, staying away from its integration process and outside ambitious international projects, including the ones in the energy and transport sector with the involvement of the territories of the 'squad'.

Despite the geostrategic role of the cooperation within ODED-GUAM in terms of the European and Euro-Atlantic aspirations of the newly established postSoviet republics, containment of political and economic expansion of Eurasian integration projects, common threats from available and frozen armed conflicts in the region, promising trade and economic projects as well as the relevance of European energy security, the organization to date has received poor attention from scholars. At the same time, the theoretical and applied study of membership patterns of individual member countries, including Moldova, is lacking. This article analyzes the domestic political aspects of the Re- 
public of Moldova's participation in the ODED-GUAM integration project. In particular, it considers the key trends of the country's membership in ODED-GUAM chronologically by the timeline of presidencies of P. Lucinschi, V. Voronin, N. Timofti, and I. Dodon. Alongside, the research assesses the prospects for Moldova's further fate as a member of the international regional organization following the 2020 presidential election victory of M. Sandu.

Key words: ODED-GUAM, Moldova, Chisinau, international regional organization, Lucinschi, Voronin, Timofti, Dodon, Sandu.

\section{REFERENCES}

1. Official Website of the President of Ukraine. Decree of the President of Ukraine No. 392/2020 «On the decision of the National Security and Defense Council of Ukraine of September 14, 2020» «On the National Security Strategy of Ukraine». President (2020). URL: https://www.president.gov.ua/documents/3922020-35037.

2. Organization for Democracy and Economic Development - GUAM. (1997). Joint Communique of the Meeting of the President of Azerbaijan, Georgia, Moldova and Ukraine. URL: https://guam-organization.org/en/joint-communique-of-themeeting-of-the-president-of-azerbaijan-georgia-moldova-and-ukraine-strasbourgoctober-10-1997.

3. Modern Ukraine, Issues 14-15. (2009). Ivan Franko National University of Lviv. Institute of Historical Research, 211.

4. Minorities at Risk Project. Chronology for Slavs in Moldova. Refworld. (2004). URL: https://www.refworld.org/docid/469f38be17.html.

5. Skakov, A. (2008). Russia and GUAM. Central Asia and the Caucasus (Special Issue), 3-4 (51-52), 142-156.

6. Ivanov, V. (2009). GUAM: Old problems and new challenges. Central Asia and the Caucasus, 4-5 (58-59), 152-159.

7. Pinzar, S. (2008). Moldova-GUAM. Central Asia and the Caucasus (Special Issue), 3-4 (51-52), 126-134.

8. Goble, P. (2009, January 29). Is Moldova about to leave GUAM? Azerbaijan International. URL: https://www.azer.com/aiweb/categories/caucasus_crisis/index/ cc_articles/goble/goble_2009/goble_0109/goble_0128_moldova.html.

9. Bugajski, J. (2009). Dismantling the West: Russia's Atlantic agenda. Washington, D.C.: Potomac Books, Inc., 257 p., p. 84.

10. Goble, P. (2009, January 29). Is Moldova about to leave GUAM?. Azerbaijan International. URL: https://www.azer.com/aiweb/categories/caucasus_crisis/ index/cc_articles/goble/goble_2009/goble_0109/goble_0128_moldova.html.

11. Cottey, A. (2012). The other Europe: Regional security governance in Europe's East. In S. Breslin \& S. Croft (Eds.), Comparative regional security governance. Abingdon: Routledge, $222 \mathrm{p}$.

12. Official Website of the United Nations. UN General Assembly Resolution 62/243 of March 14, 2008 «Situation in the Occupied Territories of Azerbaijan» 
(2008). URL: https://www.un.org/press/en/2008/ga10693.doc.htm.

13. Official Website of the United Nations. UN General Assembly Resolution 68/262 of March 27, 2014 «Territorial Integrity of Ukraine» (2014). URL: https:// digitallibrary.un.org/record/767883? $1 \mathrm{ln}=\mathrm{ru}$.

14. Civil.ge (2018, June 13). UN General Assembly Passes Georgia IDP Resolution. Civil.ge. URL: https://civil.ge/archives/244195.

15. Moldova.org (2018, June 22). The UN General Assembly adopts Moldova's resolution on the withdrawal of «foreign military forces» from its territory. Moldova.org. URL: https://www.moldova.org/en/un-general-assembly-examine-moldovas-resolution-withdrawal-foreign-military-forces-territory.

16. Official Website of the United Nations. UN General Assembly Resolution 62/249 of May 15, 2008 «Status of Internally Displaced Persons and Refugees from Abkhazia, Georgia»(2008). URL: https://www.un.org/press/en/2008/ga10708.doc. htm.

17. Gutkin, M. (2012, September 27). The President of Moldova called for the withdrawal of Russian troops from the territory of his country. Voice of America. URL: https://www.golosameriki.com/a/un-moldova-timofti/1515699.html.

18. Official Website of the United Nations. UN General Assembly Resolution $67 / 268$ of June 13, 2013 «Status of Internally Displaced Persons and Refugees from Abkhazia, Georgia, and the Tskhinvali / South Ossetia Region, Georgia»(2013). URL: https://undocs.org/en/A/RES/67/268.

19. Foreign Policy Association of the Republic of Moldova. (2012, July 13). Interview with the President of the Republic of Moldova, Nicolae Timofti, to the Lithuanian website eurodialogue.org. URL: http://www.ape.md/en/2012/07/english-interview-with-the-president-of-the-republic-of-moldova-nicolae-timofti-tothe-lithuanian-website- http-eurodialogue-org.

20. Niu, Q. (2017, June 12). Can China help GUAM diversify away from Russia? Eurasianet. URL: https://eurasianet.org/can-china-help-guam-diversify-awayfrom-russia.

21. Official Website of the President of Ukraine. The escalation in NagornoKarabakh shows that any frozen conflict could flare up again, even after many years - the President (2020). URL: https://www.president.gov.ua/news/zagostrennya-vnagirnomu-karabasi-svidchit-sho-bud-yakij-zam-64237.

22. Civil.ge (2020, October 5). Georgian President Talks Nagorno-Karabakh, Tbilisi's Neutrality. Civil.ge. URL: https://civil.ge/archives/373210.

23. Lenta.ru (2020, November 30). Sandu compared the conflicts in Transnistria and Nagorno-Karabakh. Lenta.ru. URL: https://lenta.ru/news/2020/11/30/pridnebah.

24. Palyvoda, V. (2019, June 1). «Frozen» conflicts in the post-Soviet space as a challenge to European security. National Institute for Strategic Studies. URL: https://niss.gov.ua/en/node/170.

25. Savitsky, V. (2020, November 17). Russia will not aggravate the situation in Transnistria because of Sandu's victory in Moldova. UA.NEWS. URL: https:// 
ua.news/ru/rossyya-ne-pojdyot-na-obostrenye-sytuatsyy-v-prydnestrove-yz-za-pobedy-sandu-v-moldove.

26. Aksonov, P. (2020, November 12). Why did Azerbaijan win the war in Karabakh? Military experts answer. BBC News Ukraine. URL: https://www.bbc. com/ukrainian/features-54912350.

27. Shelest, A. (2020, November 3). Elections that only aggravated the crisis: will there be a new Maidan in Georgia. European truth. URL: https:/www.eurointegration. com.ua/rus/articles/2020/11/3/7116038. 